\title{
Professional standards in museum pedagogy in the international context
}

\author{
Lucie Jagošová
}

Mgr. Lucie Jagošová, DiS.

Masaryk University

Faculty of Arts

Department of Archaeology and Museology

Arna Nováka 1

60200 Brno

Czech Republic

\&

Comenius University

Faculty of Arts

Department of Ethnology and Museology

Gondova 2

81101 Bratislava

Slovakia

email: jagosova@phil.muni.cz

\section{Professional standards in museum pedagogy in the international context}

Professional standards of museum work are defined by the clearly formulated International Council of Museums (ICOM) Code of Ethics and by the activity of professional organisations on both national and international levels. The goal to establish the general requirements for the education of museum workers was mainly pursued by the ICOM and some of its committees. Since museum pedagogy has developed into an independent discipline and museum pedagogue (educator) has became a full-value profession, the specialised commissions within individual professional organisations and the efforts of individual researchers have helped to gradually transform these general requirements into specific standards of museum pedagogy. These standards reflect both the scope of activities and necessary competencies of museum pedagogues, and the expected quality of education practice in museums (best practice). The varied views of professional standards for museum pedagogues in the international context represent a source of inspiration in the sphere of Czech museum pedagogy, which is undergoing a dynamic development in several areas of its activities (educational practice, consolidated legislative position) and gradually formulating its own professional standards.

Keywords: professional standards, museum pedagogue, museum work, museum pedagogy

\section{Introduction}

Museum pedagogues - and museum pedagogy as an independent discipline - pursue not only direct education activities within individual institutions but also strive to achieve excellence and expertise in meeting the needs of museum audiences. In the Czech Republic, the problem of professional standards in the sphere of museum pedagogy represents a relatively topical subject of interest. In the international context, this issue has been paid attention repeatedly, sometimes also in close relation to the question of ethical standards of museum work. An increased interest in museum education in the past decade is also tightly connected with changes induced by the curricular reform in the Czech school system, which enabled a broader involvement of museums in formal education. However, the development of museum pedagogy as a discipline and museum pedagogue as a profession is boosted at both the practical and theoretical levels, not only by professional standards, but also by the specialised museum practice of individual 
institutions, the possibility of professional association within the discipline, a varied offer of professional education, ${ }^{1}$ and the possibility to study international literature ${ }^{2}$ and to participate in internships.

\section{Professional standards and museum work}

The two most important factors involved in formulating the expertise and professional expectations of museums workers are ethical standards in the museum sphere generally, and the definition of certain specialised professional demands on individual jobs in museum institutions.

The basic definition of museum workers is contained in the International Council of Museums (ICOM) Code of Ethics for Museums, which emphasises their expertise, either via a professional qualification or relevant practical experience. ${ }^{3}$ Museum professions, according to basic organisational classifications, cover the areas of administration, collection care, operations and services, and education. ${ }^{4}$ They are characterised through the description of the scope of work and key activities, necessary competencies, required education and optimal practice. ${ }^{5}$ The ICOM Code of Ethics for Museums is a reference tool for museums and museum staff, which sets the minimum norms of conduct and professional behaviour; every ICOM member commits to abide by this Code. Apart from the museum's fundamental activities, ${ }^{6}$ the document also places emphasis on the relationship of museum workers to the general public

\footnotetext{
1 This is particularly of university education (above all at faculties of arts and education) and non-university education (organised by professional institutions and methodological centres for museums), supplemented by onetime seminars, workshops or conferences.

${ }^{2}$ E.g. FALK, John H. and Lynn D. DIERKING. Learning from Museums: Visitor Experiences and the Making of Meaning. Oxford: AltaMira Press, 2000; HOOPER-GREENHILL, Eilean. Museums and their Visitors. 2nd ed. London, New York: Routledge, 1996; SANDELL, Richard (ed.). Museums, Society, Inequality. London, New York: Routledge, 2002; BOYLAN, Patrick and Vicky WOOLARD. The Trainer's Manual: For Use with Running a Museum: A Practical Handbook. Paris: UNESCO, ICOM, 2006. Accessed 13 December 2019, http://unesdoc.unesco.org/ images/0014/001478/147869E.pdf; RUGE, Angelika (ed.). Frame of reference for museum professions in Europe. October 2007. Accessed 13 December 2019, http://www.kongreskultury.pl/library/File/rap.muzea/Zalacznik\%203(1). pdf; LEGGET, Jane (ed.). Staff and Training in Regional Museums. Paris: ICOM - International Committee for Regional Museums, International Committee for the Training of Personnel, Murska Sobota: Pokrajinski muzej, 2011. [Accessed 13 December 2019, http://network.icom.museum/fileadmin/user_upload/minisites/icr/pdf/ StaffAndTraining_WEB.pdf

${ }^{3}$ According to the current definition in the ICOM Code of Ethics for Museums: "Museum professionals consist of the personnel (whether paid or unpaid) of museums or institutions as defined in Article 2, paras 1 and 2, of the ICOM Statutes, who have received specialised training, or possess an equivalent practical experience in any field relevant to the management and operations of a museum, and independent persons respecting the ICOM Code of Ethics for Museums and working for museums or institutions as defined in the Statute quoted above, but not persons promoting or dealing with commercial products and equipment required for museums and museum services." LEHMANNOVÁ, Martina (ed.). Etické kodexy: Etický kodex ICOM. Etický kodex ICOM pro prírodovědná muzea. Dokument o profesi konzervátora-restaurátora. [B. m.]: Český výbor ICOM, 2014, p. 36.

${ }^{4}$ EDSON, Gary. International Directory of Museum Training. London, New York: Routledge, 1995, p. 15 sq., $36-37$.

${ }^{5}$ ZENETOU, Artemis A. Museum professional positions: Qualifications, duties, and responsibilities. In: GLASER, Jane R. and Artemis A. ZENETOU. Museums: A place to work: Planning Museum Careers. London, New York: Routledge, 1996, p. 65-123.

${ }^{6}$ Museums preserve, interpret and promote the natural and cultural inheritance of humanity; they hold primary evidence for establishing and furthering knowledge; museums that maintain collections hold them in trust for the benefit of society and its development; museums provide opportunities for the appreciation, understanding and management of the natural and cultural heritage; museums operate in a legal manner.
} 
(particularly with regards to collaboration with communities), ${ }^{7}$ professional erudition (that is, museum workers' competencies, education and shared expertise) and professional conduct. This involves familiarity with the relevant legislation, professional responsibilities, professional conduct, academic and scientific responsibilities, professional relationships and cooperation, and personal independence. Also addressed are associated aspects such as the illicit market, confidentiality of information, museum and collection security, exceptions to the obligation of confidentiality, and conflicts of interest.

The increasing general requirements for specific competencies in the content of museum work are reflected in the area of formal and informal professional education of members of the museum profession and in the formulation of both general and specialised demands on individual museum professions. As Eilean Hooper-Greenhill notes, "the professional identity of today's museum workers is characterised by constantly increasing demands on the acquired professional competencies and by the requirement of interiorisation of new strategies, values and methods. The present-day museum professionals are expected to have special competencies, particularly as regards the collections and museum audience." ${ }^{8}$

General expectations of museum and museology education, as expressed through the general curriculum of professional education in the field of museology, are defined above all by the International Council of Museums (ICOM). The activities of ICOM reflect the challenges and needs of the museum profession and are mainly focused on professional cooperation and shared expertise, the furthering of knowledge and public awareness of museums, the education of museum workers, the improvement of professional standards, and the creation and promotion of professional ethics and cultural heritage protection. The problem of professional education is mainly addressed by the International Committee for the Training of Personnel (ICTOP), which directly participates in creating and supporting the basic general curriculum for training museum professions and establishing the necessary standards. ${ }^{9}$ The ICOM Basic Syllabus for Professional Museum Training, which was issued by ICTOP in 1971 (and has subsequently been revised several times), delineated nine points within its recommended structure for educating museum workers, covering the most important areas of museum work:

1. Introduction to museology: development and mission of museums;

2. Organisation, direction and management of museums;

3. Architecture, equipment and spatial arrangement;

4. Collections: origin, associated records, system of arrangement and transport;

5. Scientific activity;

6. Protection and security of collections;

7. Exhibition making;

8. Audience;

9. Cultural and educational activity of museums.

Each of these nine umbrella areas was further split into a number of sub-topics, resulting in a document which represented a detailed standard for education in museology and museum

\footnotetext{
${ }^{7}$ Museums work in close collaboration with the communities from which their collections originate as well as those they serve; they hold resources that provide opportunities for other public services and benefits. The document also addresses, for example, the usage of collections originating from contemporary communities, displays, exhibitions and other events, interpretation of exhibits, presentation of "sensitive materials", publications and reproductions.

${ }^{8}$ HOOPER-GREENHILL, Eilean. Changing Values in the Art Museum. In: CARBONELL, Bettina Messias. Museum Studies: An Anthology of Contents. Oxford: Blackwell Publishing, 2006, p. 556-575.

${ }^{9}$ Cf. EDSON, Gary. International Directory of Museum Training. London, New York: Routledge, 1995.
} 
work. A supplement to this document (1981), in accordance with the original curriculum, emphasises the fact that despite a huge variety of activities within individual museum professions, the education of every museum worker should inevitably address five basic areas: i) museums, ii) collections, iii) administration, iv) exhibitions, displays and other public services, and v) material equipment. As a consequence of the modification of demands on education for museum professionals, the document was updated in 2000 under the title The ICOM Curricula Guidelines for Museum Professional Development (subsequently revised in 2005). It defines five more broadly-conceived areas of competence, providing a general description of the knowledge, skills and abilities necessary to work in contemporary museums, and which should be included in the design of specific educational courses and programmes:

1. General competencies;

2. Museological competencies;

3. Management competencies;

4. Museum pedagogical competencies;

5. Competencies for the administration of collections.

All five areas are further split into many sub-areas and specified by particular topics. The document thus represents a relatively detailed and sophisticated curriculum of museology education which forms the basis for creating, modifying and revising both university and nonuniversity museum and museology studies all over the world. ${ }^{10}$

The professional standards in the field of education in general are legislatively formulated in terms of professional qualities, characteristics of key professional activities, knowledge, values and attitudes most frequently characterised as a set of key professional competencies. ${ }^{11}$ The standards for professional norms and indicators of the quality of professional practice should be defined within a professional discourse and disseminated widely within the professional community. Only a shared and interiorised professional standard can be a motivation for enhancing the quality of individual activities. An indispensable role is also played by the correct professional procedures acquired through best practice, that is, identifying desirable methods and approaches that lead to the fulfilment of standards. Such an approach reflects professional problems as they arise and can offer a step-by-step procedure for solving them.

According to the American Alliance of Museums (AAM), the professional standards in the museum sphere represent generally accepted levels of attainment (determining the quality of skills) that all museums are expected to achieve. General principles of best practice for museums in the field of education and interpretation are formulated as follows:

1. The museum clearly states its overall educational goals, philosophy and messages, and demonstrates that its activities are in alignment with them.

2. The museum understands the characteristics and needs of its existing and potential audiences and uses this understanding to inform its interpretation.

3. The museum's interpretive content is based on appropriate research.

4. Museums conducting primary research do so according to scholarly standards.

5. The museum uses techniques, technologies and methods appropriate to its educational goals, content, audiences and resources.

6. The museum presents accurate and appropriate content for each of its audiences.

\footnotetext{
${ }^{10}$ In detail, see MRÁZOVÁ, Lenka and Lucie JAGOŠOVÁ. Obsahové proměny kurikula brněnské muzeologie v letech 1964-2014. In: Museologica Brunensia, 2014, no. 2, p. 28-42.

${ }^{11}$ Cf. VAŠUTOVÁ, Jaroslava. Profese učitele v českém vąélávacím kontextu. Brno: Paido, 2004.
} 
7. The museum demonstrates consistent high quality in its interpretive activities.

8. The museum assesses the effectiveness of its interpretive activities and uses those results to plan and improve its activities. ${ }^{12}$

\section{The museum pedagogue as a professional in museum education}

The development of museum pedagogy as an independent discipline generates the need to define and more precisely characterise staff members who perform practical and theoretical work in this field.

Museum pedagogues (educators) represent the key profession which helps museums fulfil their educational mission.

In museum practice, the role of museum pedagogue is usually thought of as a profession. Perspectives on a profession specialising in work with museum audiences is addressed in the texts by, for example, Elisabeth Caillet's chapter on "Which competencies for visitor services specialists? A French perspective"; ${ }^{13}$ Chen Jianming and Huang Lei's "Visitor-oriented staff training - the museological concept and practice of a museum in China"; ${ }^{14}$ and Michele Trimarchi and Maria Laura Vergelli on "Professions and promotion in the museum sector - the Italian experience". ${ }^{15} \mathrm{~A}$ museum pedagogue, with regard to the widely used terminology, can be understood as a specific profession which is well-established and relatively widespread in its professional practice (although in many cases it still has the form of a cumulative job, where museum education represents only one aspect of the professional activities in a museum). In other words, it is regarded as one of the museum professions. Not long ago (2017, with effect from 2018), this profession was provided for in the legislation pertaining to the Czech Republic's Catalogue of Public Services and Administration Jobs, ${ }^{16}$ in the section on Culture (under the terminology "educator in culture"). This provision represents the apex of efforts thus far to establish the profession of museum pedagogy. The necessary initial stages took the form of inclusion within the Czech National System of Occupations (under the terminology "museum pedagogue") and the National System of Qualifications (under the terminology "museum educator"). ${ }^{17}$ The provisions of the Act on Pedagogical Staff do not yet enable use of the

\footnotetext{
${ }^{12}$ Ethics, Standards, and Professional Practices. In American Alliance of Museums. Accessed 13 December 2019, https://www.aam-us.org/programs/ethics-standards-and-professional-practices/core-standards-for-museums/ ${ }^{13}$ CAILLET, Elizabeth. Which competencies for visitor services specialists? A French perspective. In: LEGGET, Jane (ed.) Staff and Training in Regional Museums. Paris: ICOM - ICOTP, Murska Sobota: Regional Museum, 2011. Accessed 13 December 2019, http://network.icom.museum/fileadmin/user_upload/minisites/icr/pdf/ StaffAndTraining_WEB.pdf

${ }^{14}$ JIANMING, Chen, LEI, Huang. Visitor-oriented staff training - the museological concept and practice of a museum in China. In: LEGGET (ed.) Staff and Training ...

${ }^{15}$ TRIMARCHI, Michele, VERGELLI, Maria Laura. Professions and promotion in the museum sector - the Italian experience. In LEGGET (ed.) Staff and Training ...

${ }^{16}$ See Nařzeni vlády č. 399/2017 Sb., o katalogu praci ve verejných službách a správě. 2017. Accessed 13 December 2019, https://www.mpsv.cz/files/clanky/32127/NV_399_2017_1_1_2018_.pdf

${ }_{17}$ See Muzejní pedagog. In Národni soustava povolání. Praha: Ministerstvo práce a sociálních věcí. Accessed 13 December 2019, http:/ / katalog.nsp.cz/karta_p.aspx?id_jp=102314; Muzejní edukátor. In Národni soustava kvalifikací. Praha: Národní ústav pro vzdělávání, 2006-2014. Accessed 13 December 2019, https://www.narodnikvalifikace.cz/ kvalifikace-1123-Muzejni_edukator
} 
term pedagogue in relation to the role fulfilled by museum pedagogues, ${ }^{18}$ which undoubtedly affects the still insufficiently exploited potential of museums as institutions in both formal and informal public education.

The obligation for cultural institutions to be involved in education in the Czech Republic is contained in the document State Cultural Policy for 2015-2020 (with an outlook until 2025) and the issue of museum education is also included in the Concept of Museum Development in the Czech Republic in 2015-2020. The present effort to increase the professionalisation of museums logically tends not only to deepen the professional competencies, but also to intensify and improve cooperation between various museum professions, individual museums and related institutions at various levels of museum work. ${ }^{19}$ However, in practice we often encounter a lack of awareness of the more detailed characterisation, the high level of expertise, and the real scope of work involved in being a museum pedagogue. The most distinct shift in this aspect in the past few years can be ascribed to developments in university education (further development of existing models and the emergence of new independent fields and specialisations in the follow-up to Master's studies), the development of new and existing forms of non-university education (courses, seminars) and, above all, the lively display of interest in all these forms. With respect to these historical developments (which, in the Czech and Slovak milieu, have mainly occurred in the last decade) it can be said that after the predominant monothematic orientation on case reports (so-called examples of best practice in creation of accompanying programmes), the spectrum of professional activities considered to lie within the scope of museum pedagogues has been extended in a desirable way. Furthermore, the focus has shifted, for example, to include more didactic methods and approaches, emphasise the pedagogical and psychological aspects of the work with various audiences, and to focus on reflecting on one's own work and provide support for further education through one-off seminars and longer courses).

In contrast to the professional community's significant interest in museum pedagogy as a whole, much less attention has been paid, in terms of publications and empirical research, to studying museum pedagogy as a profession. The major part of the research which has been conducted is tightly connected with the practical activities of museum pedagogues. Emphasis is put either on didactic activities (didactic methods and approaches), or on the community of visitors and their stratification (principles of pedagogical and psychological influence on individual audiences). To this day, we have only minimal research data on the profession and

\footnotetext{
${ }^{18}$ According to this Act, a pedagogical staff member, i.e. pedagogue, is narrowly defined as a worker who performs educational activity in a school or educational institution enlisted in the Registry of Schools and Educational Institutions, or in a social services facility. See Platné znění části první zákona č. 563/2004 Sb., o pedagogických pracovnících a o změně některých zákonů, s vyznačením navrhovaných změn a doplnění: Zákon č. 563/2004 Sb., o pedagogických pracovnících a o změně některých zákonů. In Ministerstvo školství, mláde že a tělovýchory. Praha: Ministerstvo školství, mládeže a tělovýchovy, 2013-2019. Accessed 13 December 2019, http://www.msmt.cz/ file/34285/>.

${ }^{19}$ JAGOŠOVÁ, Lucie, Otakar KIRSCH et al. Muzejni profese a verégnost 1. Nástin historie a současnosti vzájemných vżtabĩ muzei a jejich publika. Brno: Masarykova univerzita, 2016. Accessed 13 December 2019, https://archeo-muzeo.phil. muni.cz/media/3056324/muzejni_profese_a_verejnost.pdf
} 
community of museum pedagogues and on their education. ${ }^{20}$

Professional standards in museum pedagogy in the international context

The problem of professional standards for museum pedagogues has already been addressed in the international literature, for example, in a short article from 1989 in the Journal of Museum Education; ${ }^{21}$ however, this issue is mostly treated from methodological and practical perspectives by the professional organisations associated with museum pedagogy.

The International Council of Museums (ICOM), in connection with its International Committee for Education and Cultural Action (CECA), refers to three documents on its website in the area concerned with museum education and cultural activities: Best Practice in Museum Education and Cultural Programmes (CECA); Best Practice Books (6 volumes), (ICOMCECA/Edizioni Nuova Cultura, 2017); and Education Toolkit, Methods and Techniques from Museum and Heritage Education (ICOM-CECA/LCM/Erfgoedhuis Zuid-Holland, 2017). ${ }^{22}$ The CECA committee uses best practice as a tool for analysing an educational or cultural project that has been developed, in accordance with the responsibilities of CECA members to share any management tools that can bring them near to the "model project". This tool was proposed by Marie-Clarté O’Neill and Colette Dufresne-Tassé, and the topic has since been increasingly discussed at the European and global levels in annual conferences and regional workshops. The three goals of publishing this document are as follows: to manage and critically review the work of CECA members and supporters on conceiving, analysing and evaluating their educational and cultural projects; to instigate and support institutions and professionals in creating projects at the relevant level (in a comparable way), either individually, or within national or international groups; and to support the revision and broadening of programme presentations in annual meetings. In connection with supporting best practice, CECA offers an annual Best Practice Award and issues volumes of the Best Practice Book, presenting the results of professional activities and research conducted by CECA members since 2012. ${ }^{23}$

The hitherto not very deeply elaborated international Professional Standards for Museum Educators $(2005)^{24}$ were formulated by the Education Committee (EdCom) of the American Alliance of Museums (AAM). Professional standards, from their perspective, represent a professional consensus about the "best practice". The process by which the standards evolve relies on the involvement of experts in the given area, who codify a suitable set of professional activities on the basis of a broad spectrum of experience. The standards are only recommended and their

\footnotetext{
${ }^{20}$ See, for example, STUCHLÍKOVÁ, Alice. Profese galerijního pedagoga. PhD thesis. Brno: Masarykova univerzita, Pedagogická fakulta, Katedra výtvarné výchovy, 2012. Accessed 13 December 2019, http://www.is.muni.cz; JAGOŠOVÁ, Lucie and Jitka KRÁLOVÁ. Aktuální kontury profese muzejního pedagoga. Reflexe kvalifikační profilace pracovníků v oblasti muzejní pedagogiky na př́kladu Komise pro práci s veřejností a muzejní pedagogiku AMG ČR. In: Muzeológia a kultúrne dedirsttvo, vol. 5, no. 2, 2017, p. 141-153.

${ }^{21}$ WILLIAMS, Patterson. Professional Standards for Museum Educators. In: Journal of Museum Education vol. 14, no. 3, 1989, p. 11-13. Accessed 13 December 2019, https://www.tandfonline.com/doi/abs/10.1080/10598650.19 89.11510119

${ }^{22}$ Standards. In: ICOM. Accessed 13 December 2019, https://icom.museum/en/activities/standards-guidelines/ standards/

${ }^{23}$ Best Practice. In ICOM International Committee for Education and Cultural Action. Accessed 13 December 2019, http:// ceca.mini.icom.museum/publications-2/best-practice/

${ }^{24}$ Excellence in Practice: Museum Education Principles and Standards. Washington: American Association of Museums, 2005, p. 10. Accessed 13 December 2019, http://ww2.aam-us.org/docs/default-source/accreditation/committeeon-education.pdf?sfvrsn=0
} 
aim is to support excellence through the development of criteria for evaluating (interpretive) efficiency. The professional standards offered by EdCom are based on three foundation stones: accessibility, accountability and advocacy. The document elaborates them out to six basic points:

1. a focus on audience and community;

2. diversity of perspectives - respect and understanding;

3. excellence in content and methodology of museum education;

4. advocacy for audiences - collaboration within the museum to promote the best interests of audiences;

5. advocacy for education's role in advancing the mission and goals of the museum;

6. dedication to learning and a commitment to nurture and develop an informed and humane citizenry.

However, the American Alliance of Museums also pays attention to the formulation of standards of professional work in other areas, which may be of key importance for museum pedagogues who participate in these activities as museum staff members. The most relevant example might be the area of museum exhibitions and the document Standards for Museum Exhibitions and Indicators of Excellence. ${ }^{25}$ The standards for museum exhibitions are organised into seven major and closely linked categories, followed by a detailed description (of what constitutes effectiveness for each category, and the listing of specific ways the category might be expressed in an exhibition):

1. Audience awareness. (The exhibition is developed with an articulated understanding of the intended visitors' prior knowledge, interests, learning styles, attitudes and expectations about the topic and the experiences planned for visitors.)

2. Evaluation. (Evaluation studies are conducted during development and/or after opening the exhibition to understand its impact on audiences in relation to the project's goals.)

3. Content. (Content is thoroughly researched and vetted for accuracy, relevance to exhibition theme/s, and the current state of knowledge of the topic.)

4. Collections. (The selection and presentation of objects furthers the intellectual content of the exhibition.)

5. Interpretation/communication. (The information/message of the exhibition is clear and coherent. If not, there is a good reason why not.)

6. Design and production. (The selection, design and production of interpretive media which effectively and engagingly communicate content.)

7. Human comfort, safety and accessibility. (The exhibition is designed such that the experience of the visitor, including their physical, intellectual and social well-being, is taken into account.)

The problem of professional standards and best practice has been addressed not only by international and national professional organisations, but also by individual authors who conduct research in this area and have published many works, from short studies through to extensive treatises. These works, moreover, may provide a counterweight to globally conceived recommendations and may better reflect the specifics of museum education (or only some aspects from among the wide spectrum of professional activities) in local conditions and

\footnotetext{
${ }^{25}$ Standards for Museum Exhibitions and Indicators of Excellence. American Alliance of Museums, August 2012. Accessed 13 December 2019, https:/ / static1.squarespace.com/static/58fa260a725e25c4f30020f3/t/58ff73ed3e00bea8e746d 4ce/1493136367751/2012+Standards+for+Museum++Exhibitions+and+Indicators+of+Excellence.pdf
} 
practice. Examples include the works by Eva M. Reussner (2004; Australia and New Zealand) ${ }^{26}$ and Susan Krogh Jensen (2019; Denmark). ${ }^{27}$

With regard to the fact that the Czech (and Slovak) museum sector is still gradually elaborating the professional standards for museum pedagogy, their current form can be only derived from the demands for professional competencies or based on the competency model outlined within the requirements for qualifications for museum educators. The standards can also be inspired by international activities in this field.

In the Czech Republic, the Committee for Public Relations and Museum Pedagogy, which exists within the Czech Association of Museums and Galleries, published, more than five years ago, its generally formulated view, which sees the mission of a museum pedagogue as someone who supports:

1. collaboration with other professional and interest associations within the discipline and interdisciplinary cooperation;

2. the development of the theoretical, methodical, methodological and practical base of the discipline in cooperation with academic institutions and methodological centres;

3. the formation and activity of working groups within the Committee for Public Relations and Museum Pedagogy, in accordance with topical trends and the needs of the discipline;

4. professional education;

5. the continuous mapping of the development and transformations of the museum pedagogical community, professional standards and trends in museum education;

6. the profession of museum pedagogues, their professionalisation and their stable position in the labour market.

The committee then formulated preliminary recommendations for the educational activity of museum pedagogues, which were based on the following general points on the spectrum of their expected activity (not only within institutions, but also within professional associations and education):

1. Museums should serve the public, not the other way around.

2. Museums are not only exhibitions.

3. Inspiration should be sought abroad.

4. The educator should be given a suitable position in the exhibition team.

5. The educator should share expertise with colleagues.

6. Programmes should be funded from the museum's budget.

7. Museums should focus on establishing a high-quality media policy. ${ }^{28}$

Reflections on best practice and on the professional community of museum pedagogues in the Czech Republic was later better formulated through a characterisation of museum pedagogues/ educators (mainly of the scope of their work) in the Czech National System of Occupations, created with significant support from the international literature dealing with this profession, the scope

\footnotetext{
${ }^{26}$ REUSSNER, Eva M. Best Practices in Audience Research and Evaluation Case Studies of Australian and New Zealand Museums. Visitor Studies Today, vol. 7, no. 2, Summer 2004. Accessed 13 December 2019, http://kora. matrix.msu.edu/files/31/173/1F-AD-27A-8-VSA-a0a6b1-a_5730.pdf

${ }^{27}$ JENSEN, Susanne Krogh. From Generalist to Specialist: The Professionalization of the Danish Museum Occupation 19582018. PhD thesis. Copenhagen: University of Copenhagen, 2019.

${ }^{28}$ Hlavní programové linie činnosti: Strategie výboru komise pro práci s veřejností a muzejní pedagogiku AMG a doporučení pro muzejněpedagogickou praxi. In Asociace muzeí a galerii České republiky. Accessed 13 December 2019 , http://www.cz-museums.cz/web/amg/organy-amg/komise/komise-pro-praci-s-verejnosti-a-muzejnipedagogiku/hlavni-programove-linie-cinnosti
} 
of its activities and the required competencies. ${ }^{29} \mathrm{~A}$ distinct shift in the formulation of demands on museum pedagogues within the competency model of the curriculum appeared with the establishment of a qualification standard for museum educators, which was included in the National System of Qualifications, with effect from 2016. The qualification standard defines eight areas of professional competence:

1. Familiarity with the current situation in museum education at home and abroad.

2. Ability to elaborate the museum's concept of and strategy for education.

3. Familiarity with pedagogical and psychological concepts related to museum education.

4. Ability to define the objectives of museum education.

5. Concept and elaboration of the museum's educational programme.

6. Ability to select and use appropriate didactical methods and forms of museum education.

7. Ability to present educational activity in the museum.

8. Ability to apply professional conduct and communication in museum education.

Each of these areas is further divided into several sub-areas. Candidates interested in taking acquiring the professional qualification of Museum educator (code: 82-041-T) ${ }^{30}$ are examined on their knowledge and skills in all these areas. The study materials for this qualification exam address all areas in detail. ${ }^{31}$

The gradually refined view of museum pedagogy as a highly skilled profession with clearly formulated competencies, a specific scope of professional activities and continuously defined working standards is currently projected into the new concepts of study programmes, along with new legislative changes of the accreditation system of university studies in the Czech Republic. Several more-or-less traditional study programmes which train museum pedagogues for practical work in museums regularly revise their curricula and update the expected profile of their graduates. The current increase of interest in the problem offers space for the creation of university study programmes as well as completely new formats.

\section{Conclusion}

The social significance of cultural identity, and of the collection, preservation and presentation of cultural heritage to the general public in which the museum pedagogue takes an active part, is beyond any doubt. The museum pedagogue occupies a key position, as a link between the content/information and its recipient, and is responsible for the quality of this mediation process. Such professionals ensure that appropriate methods are applied to the educational aspects of the museum's activities, and that the institution's communications are easily understandable, as well as intellectually and emotionally effective. Deeper study of the profession of museum pedagogy and the community of people working in the field of museum education, as well as a clearer formulation of professional standards which take into account local conditions, can bring into the sphere of museums and museology a deeper understanding and more effective exploitation of the educational potential of museums in practice, and provide theoretical and empirical support and development for those studying to become a museum pedagogue.

\footnotetext{
${ }^{29}$ See mainly the literature cited in notes 5,4 and 2.

${ }^{30}$ Muzejní edukátor. In: Národní soustava kvalifikací. Praha: Národní ústav pro vzdělávání, 2006-2014. Accessed 13 December 2019, https://www.narodnikvalifikace.cz/kvalifikace-1123-Muzejni_edukator

${ }^{31}$ Muzejni edukátor: Studijni materiál. Brno: Moravské zemské muzeum, 2019. Accessed 13 December 2019, http:// www.mcmp.cz/fileadmin/user_upload/vzdelavani/STUDIJNI_MATERIAL_2019.pd
} 


\section{References}

Best Practice. In ICOM International Committee for Education and Cultural Action. Accessed 13 December 2019, http:/ / ceca.mini.icom.museum/publications-2/best-practice/

BOYLAN, Patrick J. (ed.) (1994). Museums 2000: Politics, People, Professionals and Profit. London: Routledge.

BOYLAN, Patrick J. (ed.) (2004). Running a Museum: A Practical Handbook. Paris: ICOM. Accessed 13 December 2019, https://unesdoc.unesco.org/ark:/48223/pf0000141067

BOYLAN, Patrick and Vicky WOOLARD (2006). The Trainer's Manual: For Use with Running a Museum: A Practical Handbook. Paris: UNESCO, ICOM. Accessed 13 December 2019, http://unesdoc.unesco.org/images/0014/001478/147869E.pdf

BRÜNINGHAUS-KNUBEL, Cornelia (1993). Museum educator: the audience's advocate. Museum International, vol. 45, no. 4, p. 13-17.

EDSON, Gary (1995). International Directory of Museum Training. London, New York: Routledge.

Ethics, Standards, and Professional Practices. In: American Alliance of Museums. Accessed 13 December 2019, https://www.aam-us.org/programs/ethics-standards-and-professionalpractices/core-standards-for-museums/

Excellence in Practice: Museum Education Principles and Standards. Washington: American Association of Museums, 2005. Accessed 13 December 2019http://ww2.aam-us.org/docs/defaultsource/accreditation/committee-on-education.pdf?sfvrsn $=0$

FALK, John H., DIERKING, Lynn D. (2000). Learning from Museums: Visitor Experiences and the Making of Meaning. Oxford: AltaMira Press.

FIALOVÁ, Dagmar (2003). Profesni a etické standardy a výkonnostni ukazatele muzejni práce. Praha: Asociace muzeí a galerií ČR.

FOLDS, Thomas (1970). Educational Personnel in Museums. In Training of museum personnel: La formation du personnel des musees. Paris: ICOM, p. 48-75.

Hlavní programové linie činnosti: Strategie výboru komise pro práci s veřejností a muzejní pedagogiku AMG a doporučení pro muzejněpedagogickou praxi. In: Asociace muzeí a galerii Ceské republiky. Accessed 13 December 2019, http://www.cz-museums.cz/web/ amg/organy-amg/komise/komise-pro-praci-s-verejnosti-a-muzejni-pedagogiku/hlavniprogramove-linie-cinnosti

HOOPER-GREENHILL, Eilean (2006). Changing Values in the Art Museum. In: CARBONELL, Bettina Messias (ed.) Museum Studies: An Anthology of Contents. Oxford: Blackwell Publishing, p. 556-575.

HOOPER-GREENHILL, Eilean (1996). Museums and their Visitors. 2nd ed. London, New York: Routledge.

ICOM Curricula Guidelines for Museum Professional Development: ICTOP Museum Career Development Tree. 2009. Accessed 13 December 2019, http://network.icom.museum/fileadmin/user_ upload/minisites/icme/pdf/Conference_papers/2004-2005/ICME_2004_boylan.pdf

JAGOŠOVÁ, Lucie, KRÁLOVÁ, Jitka (2017). Aktuální kontury profese muzejního pedagoga. Reflexe kvalifikační profilace pracovníků v oblasti muzejní pedagogiky na príkladu Komise pro práci s veřejností a muzejní pedagogiku AMG ČR. In: Muzeológia a kultúrne dedičstvo, vol. 5 , no. 2 , p. 141-153. 
JAGOŠOVÁ, Lucie et al. (2016). Muzejni profese a verejnost 1. Nástin historie a soúáasnosti vájemných v₹̨tabi muzei a jejich publika. Brno: Masarykova univerzita. Accessed 13 December 2019, https://archeo-muzeo.phil.muni.cz/media/3056324/muzejni_profese_a_verejnost.pdf

JAGOŠOVÁ, Lucie, JƯVA, Vladimír, MRÁZOVÁ, Lenka (2010). Murejni pedagogika: Metodologické a didaktické aspekty muzejni edukace. Brno: Paido.

JENSEN, Susanne Krogh (2019). From Generalist to Specialist: The Professionalization of the Danish Museum Occupation 1958-2018. PhD thesis, Copenhagen: University of Copenhagen.

LEGGET, Jane (ed.) (2011). Staff and Training in Regional Museums. Paris: ICOM - ICOTP, Murska Sobota: Regional Museum. Accessed 13 December 2019, http://network.icom. museum/fileadmin/user_upload/minisites/icr/pdf/StaffAndTraining_WEB.pdf

LEHMANNOVÁ, Martina (ed.) (2014). Etické kodexy: Etický kodex ICOM. Etický kodex ICOM pro prírodovédná muzea. Dokument o profesi konzervátora-restaurátora. [B. m.]: Český výbor ICOM.

MRÁZOVÁ, Lenka, JAGOŠOVÁ, Lucie (2014). Obsahové proměny kurikula brněnské muzeologie v letech 1964-2014. Museologica Brunensia, no. 2, p. 28-42.

Muzejní edukátor. In Národni soustava kvalifikací. Praha: Národní ústav pro vzdělávání, 20062014. Accessed 13 December 2019, https://www.narodnikvalifikace.cz/kvalifikace-1123Muzejni_edukator

Muzejni edukátor: Studijni material (2019). Brno: Moravské zemské muzeum. Accessed 13 December 2019, http://www.mcmp.cz/fileadmin/user_upload/vzdelavani/STUDIJNI_ MATERIAL_2019.pdf

Muzejní pedagog. In Národni soustava povolání. Praha: Ministerstvo práce a sociálních věcí. Accessed 13 December 2019, http://katalog.nsp.cz/karta_p.aspx?id_ ip $=102314$

Nař́zeni vlády č. 399/2017 Sb., o katalogu praci ve verejných službách a správě (2017). Accessed 13 December 2019, https:/ /www.psp.cz/sqw/sbirka.sqw?cz=399\&r=2017

Platné znění části první zákona č. 563/2004 Sb., o pedagogických pracovnících a o změně některých zákonů, s vyznačením navrhovaných změn a doplnění: Zákon č. 563/2004 Sb., o pedagogických pracovnících a o změně některých zákonů. In Ministerstvo školství, mláde že a tělovýchovy. Praha: Ministerstvo školství, mládeže a tělovýchovy, 2013-2019. Accessed 13 December 2019, http:/ /www.msmt.cz/file/34285/

REUSSNER, Eva M. (2004). Best Practices in Audience Research and Evaluation Case Studies of Australian and New Zealand Museums. Visitor Studies Today, vol. 7, no. 2. http://kora. matrix.msu.edu/files/31/173/1F-AD-27A-8-VSA-a0a6b1-a_5730.pdf

RUGE, Angelika (ed.) (October 2007). Frame of reference for museum professions in Europe. Accessed 13 December 2019, https://www.yumpu.com/en/document/view/6377214/museumprofessions-a-european-frame-of-reference-the-

SANDELL, Richard (ed.) (2002). Museums, Society, Inequality. London, New York: Routledge. Standards. In ICOM. Accessed 13 December 2019, https://icom.museum/en/resources/ standards-guidelines/standards/

Standards for Museum Exbibitions and Indicators of Excellence. American Alliance of Museums, August 2012. Accessed 13 December 2019, https://static1.squarespace.com/ static/58fa260a725e25c4f30020f3/t/58ff73ed3e00bea8e746d4ce/1493136367751/2012+ Standards+for+Museum ++ Exhibitions + and +Indicators + of + Excellence.pdf 
STUCHLÍKOVÁ, Alice (2012). Profese galerijního pedagoga. PhD thesis. Brno: Masarykova univerzita, Pedagogická fakulta, Katedra výtvarné výchovy. Accessed 13 December 2019, http://www.is.muni.cz

TALBOYS, Graeme K. (2011). Museum Educator's Handbook. Farnham: Ashgate.

TRAN, Lynn Uyen, KING, Heather (2007). The Professionalization of Museum Educators: The Case in Science Museums. Museum Management and Curatorship, no. 2, p. 131-149.

VAŠUTOVÁ, Jaroslava (2004). Profese učitele v českém vzdèlávacím kontextu. Brno: Paido.

WILLIAMS, Patterson (1989). Professional Standards for Museum Educators. Journal of Museum Education, vol. 14, no. 3, p. 11-13. Accessed 13 December 2019, https://www.tandfonline. com/doi/abs/10.1080/10598650.1989.11510119

WOOLARD, Vicky (2009). An Unsettled Profession. In LANG, Caroline et al. (eds.) The Responsive Museum: Working with Audiences in the Twenty-First Century. Farnham: Ashgate, p. 211-222.

ZENETOU, Artemis A. (1996). Museum professional positions: Qualifications, duties, and responsibilities. In: GLASER, Jane R., ZENETOU, Artemis A. Museums: A place to work: Planning Museum Careers. London, New York: Routledge. 